\title{
SUBDESENVOLVIMENTO ECONÔMICO NA CADEIA GLOBAL DO PETRÓLEO: 0 CASO DA VENEZUELA
}

\author{
Mauro Sérgio Figueira ${ }^{1}$
}

RESUMO: O objetivo deste trabalho é observar a experiência de subdesenvolvimento da Venezuela entre os anos 1945 e 1990 por meio de uma integração teórica entre a tradição epistemológica cepalina latino-americana e a tradição da análise das cadeias globais de mercadorias. O problema que guia a pesquisa é encontrar o nexo político e histórico entre o processo de subdesenvolvimento da Venezuela e a dependência econômica em relação ao petróleo, principal produto produzido e comercializado pelo país. Qual é a relação entre o processo de subdesenvolvimento da Venezuela e o desenvolvimento da economia mundial capitalista? É possível explicar o subdesenvolvimento econômico do país utilizando como variável os eventos da política mundial? Nossa hipótese é a de que o nexo entre a economia venezuelana e a cadeia global de poder do petróleo responde por parte de seu processo histórico de subdesenvolvimento. A hipótese decorre da utilização do conceito de cadeia global de poder da mercadoria, que derivamos da tradição da análise dos sistemas mundiais para investigar a estrutura político-econômica e as determinações históricas dentro das quais os processos de desenvolvimento e subdesenvolvimento ocorrem. Argumentamos, em suma, que o processo de subdesenvolvimento da Venezuela pode e deve ser entendido com referência aos eventos políticos na cadeia global do petróleo entre 1945 e 1990.

Palavras-chave: Petróleo; Venezuela; Subdesenvolvimento; Cadeias Globais de Poder.

\section{UNDERDEVELOPMENT IN THE GLOBAL OIL CHAIN: THE VENEZUELAN}

\section{CASE}

ABSTRACT: The goal of this paper is to observe Venezuela's underdevelopment experience in the years 1945-1990 through the theoretical integration of CEPAL and global commodity chains traditions. O problem guiding this research is to find the political and historical links between the underdevelopment process and its oil dependence. What is the relation between Venezuela's underdevelopment process and the development of the capitalist world

\footnotetext{
${ }^{1}$ Mestre em Relações Internacionais, com ênfase em Economia Política Internacional, pela Universidade Federal de Santa Catarina (2017). Este trabalho é resultado da dissertação de mestrado do autor, com apoio da Coordenação de Aperfeiçoamento de Pessoal de Nível Superior. Endereço Eletrônico: maurofigueira@ hotmail.com.
} 
economy? Is it possible to explain the economic underdevelopment using the events of global politics as a variable? Our hypothesis is that link between the Venezuelan economy and the global oil power chain accounts for part its historical underdevelopment process. The hypothesis is drawn from the concept of global commodity power chain, which we derive from the world system analysis to investigate the political economic structure and the historical determinations in which development and underdevelopment processes occur. In sum, we argue that the Venezuelan underdevelopment process can be understood with regard to political events in the global oil chain in the years 1945-1990.

Keywords: Oil; Venezuela; Underdevelopment; Global Power Chains.

\section{SUBDESENVOLVIMIENTO ECONÓMICO EN LA CADENA GLOBAL DEL PETRÓLEO: EL CASO DE VENEZUELA}

Resumen: El objetivo de este trabajo es observar la experiencia de subdesarrollo de Venezuela entre los años 1945 y 1990 por medio de una integración teórica entre la tradición epistemológica cepalina latino-americana y la tradición del análisis de las cadenas globales de mercancías. El problema que guía esta investigación es encontrar el eslabón político e histórico entre el proceso de subdesarrollo de Venezuela y la dependencia económica del petróleo, principal producto producido y exportado por el país. ¿Cuál es la relación entre el subdesarrollo de Venezuela y la economía mundial capitalista? ¿Es posible explicar el subdesarrollo económico del país utilizando los eventos de la política mundial como variable? Nuestra hipótesis es la de que el eslabón entre la economía venezolana y la cadena global de poder del petróleo responde por parte de su proceso histórico de subdesarrollo. La hipótesis resulta de la utilización del concepto de cadena global de poder de la mercancía, que derivamos de la tradición del análisis de los sistemas mundiales para investigar la estructura político-económica y las determinaciones históricas dentro de las cuales ocurren los procesos de subdesarrollo. Argumentamos, en suma, que el proceso de subdesarrollo de Venezuela puede y debe ser comprendido con referencia a los eventos políticos en la cadena global de poder de petróleo entre 1945 y 1990.

Palabras Clave: Petróleo; Venezuela; Subdesarrollo; Cadenas Globales de Poder.

\section{Introdução}

A Venezuela, ao longo do século XX, consolidou sua dependência da atividade de produção e comércio do petróleo, com consequências contraditórias para sua experiência nacional. Em janeiro de 2016 a Venezuela vendia seu petróleo a cerca de USD21,00 por barril - após aquele longo período de altas - a um custo de cerca de USD18,00 o barril, o que desencadeou uma situação que o próprio presidente Nicolás Maduro classificou como “catastrófica” em discurso recente, além dos próprios indicadores econômicos nada otimistas (Adghirni, 2016). As reservas internacionais em dólar diminuíram de USD43bi em 2008 para USD15bi em 2015; o aumento do endividamento externo, da pobreza, desemprego e inflação evidenciam o contexto dificultoso no país sul americano (idem). Tal cenário, contudo, não é 
apenas episódico ou decorrente de desvios de ordem governamental no caso da Venezuela, mas sim decorrente de uma situação estrutural daquele país. Como veremos, o processo de desenvolvimento da Venezuela ao longo do século XX confiou excessivamente nas rendas oscilantes da exportação de petróleo para o financiamento de sua experiência econômica.

O objetivo deste trabalho é observar a experiência de subdesenvolvimento da Venezuela entre os anos 1945 e 1990 por meio de uma integração teórica entre a tradição epistemológica cepalina latino-americana e a tradição da sociologia histórica, com foco na análise sistêmica das cadeias globais de mercadorias. A primeira aborda os casos de subdesenvolvimento como problema histórico decorrente da vinculação da economia nacional ao excedente produzido por agentes estrangeiros, gerando dependência e vulnerabilidade. A segunda irá nos apontar para as determinações políticas e históricas dessa dependência e vulnerabilidade.

A literatura compreende amplamente que as dificuldades econômicas da Venezuela estão associadas à sua dependência em relação à exportação de petróleo, levando em conta que essa commodity é grande responsável pela arrecadação físcal governamental e pela demanda agregada doméstica, puxando os investimentos privados (Karl, 1997; Schuldt \& Acosta, 2006; Jeannot, 2010; Rossi, 2011; Hammond, 2011; Wilpert, 2013). Pouco se investiga, porém, qual o nexo da política mundial do petróleo com essa volatilidade e dependência. Com essa problemática, buscamos investigar as seguintes questões: Qual é a relação entre o processo de subdesenvolvimento da Venezuela e o desenvolvimento da economia-mundo capitalista? É possível explicar o subdesenvolvimento econômico do país utilizando como variável os eventos da política mundial?

Nossa hipótese é a de que o nexo entre a economia venezuelana e a cadeia global de poder do petróleo responde por parte de seu processo histórico de subdesenvolvimento. A hipótese decorre da utilização do conceito de cadeia global de poder da mercadoria, que derivamos da tradição da análise dos sistemas mundiais para investigar a estrutura políticoeconômica e as determinações históricas dentro das quais os processos de desenvolvimento e subdesenvolvimento ocorrem. Argumentamos, em suma, que o processo de subdesenvolvimento da Venezuela pode e deve ser entendido com referência aos eventos políticos na cadeia global do petróleo entre 1945 e 1990.

Este artigo está composto por mais cinco seções após esta introdução. Na próxima seção, delineamos as orientações teóricas do subdesenvolvimento e da cadeia global de poder da mercadoria que nos guiarão na descrição histórica das seções seguintes. Na terceira seção, 
veremos o desenvolvimento histórico da cadeia global de poder do petróleo entre 1945 e 1990, dividido em três fases: a primeira, entre 1945 e 1968, a montagem da cadeia e seus elos constitutivos; a segunda, entre 1968 e 1980, o recrudescimento de conflitos competitivos e a sucumbência dos elos da cadeia, resultando na desorganização completa da cadeia de poder e em uma crise de hegemonia; a terceira e derradeira, entre 1974 e 1990, a reorganização dos elos da cadeia e a retomada da hegemonia sobre novas bases. Na quarta seção, abordaremos a experiência econômica da Venezuela entre os anos 1945 e 1990. Na quinta seção, faremos a discussão da integração teórica e verificaremos a aplicação da hipótese e do conceito. Nas considerações finais, esperamos resumir em poucas linhas os argumentos centrais do trabalho.

\section{Subdesenvolvimento econômico e a cadeia global de poder do petróleo}

Proliferou-se, ao longo do século XX, uma constelação diversificada de tentativas de precisar o desenvolvimento ${ }^{2}$. Para resumir, segundo Todaro e Smith (2003), o desenvolvimento econômico referia-se a dois eventos principais: i) a mudança estrutural relativamente rápida, promovida por algum grau de coordenação consciente e planejada da sociedade; ii) a utilização dos frutos da mudança estrutural para melhorar o padrão de vida de grande parte da população de uma comunidade. Por sua vez, o subdesenvolvimento fora tratado, em sua pluralidade, como etapa anterior ao desenvolvimento, como atraso no desenvolvimento ou como contraparte inseparável do desenvolvimento do capitalismo, dependendo dos postulados científicos adotados (cf. Chase-Dunn, 1998).

Algumas indicações no pensamento social brasileiro são valiosas para o tratamento objetivo da matéria. Parte dessas indicações valiosas remetem aos apontamentos de Celso Furtado $(1983 ; 2009)$ acerca do desenvolvimento e do subdesenvolvimento, formulados em suas obras dos anos 1950 e 1960. Nessas obras, o autor se refere processo de desenvolvimento econômico fundamentalmente como um processo de acumulação de capital, o que significa a produção de excedente que se transforme em meio de produção (capital) e retorne ao processo econômico, substituindo o trabalho manual por operações e técnicas novas e mais complexas que aumentem a produção de excedente ${ }^{3}$ (Furtado, 2009, p. 94).

\footnotetext{
2 Acompanhando a tentativa de precisar o sentido da palavra, surgiram interpretações e diagnósticos sobre as causas do desenvolvimento, bem como do atraso relativo no desenvolvimento. As principais lembradas hoje são as de Rostow (1961), Hirschman (1958), Prebisch (1949), Perroux (1969), Myrdal (1957) e inúmeros outros (cf. Moraes, 2006; Gumiero, 2011; Lima, 2015).

3 Como mostra Gumiero (2011), o entendimento de Celso Furtado acerca do desenvolvimento e do subdesenvolvimento seguiu a tendência de complexificação durante o século XX. Nos escritos tardios do economista cepalino, o desenvolvimento deveria necessariamente abarcar o incremento da capacidade 
Dado o caráter histórico-estrutural das formulações de Furtado sobre o desenvolvimento econômico, o autor defendeu a proposição de que o processo de subdesenvolvimento acontecia a nível global de modo simultâneo ao desenvolvimento e, possuía, por si só, mecanismos que o reproduziam e que deveriam ser explorados à luz de sua especificidade histórica. O que é central para Celso Furtado nas economias subdesenvolvidas é justamente a insuficiência de geração de excedente que retorne à produção na forma de capital. A vinculação dos países subdesenvolvidos à economia internacional por meio de empresas capitalistas estrangeiras faz com que parte significativa do excedente gerado naquele território seja revertida à sede das corporações e não é reinvestido no país em questão. Ou seja, o principal elemento dinamizador do capitalismo, o excedente doméstico, não está presente nas regiões subdesenvolvidas. Nas etapas cíclicas de alta dos preços do produto exportado pela região subdesenvolvida, a empresa estrangeira, via de regra, capta a maior parte dos lucros e os redireciona para sua sede. O resultado é a existência de uma estrutura econômica permanentemente dependente do setor externo para auferir o excedente necessário para transformar em capital, elevar a produtividade e promover o desenvolvimento econômico. Tem-se, com isso, a principal característica das economias subdesenvolvidas contemporâneas (Furtado, 2009, pp. 163-5).

As formulações de Furtado para o subdesenvolvimento apontam, portanto, para uma associação não negligenciável entre a economia nacional, agentes capitalistas estrangeiros e o ambiente econômico internacional como um todo. Propomos que o nexo entre os dois ambientes - as economias doméstica e internacional - pode ser operacionalizado com o conceito de cadeias globais.

Os territórios econômicos "soberanos" no capitalismo são assimilados e integrados pelos agentes capitalistas por meio de cadeias de produção e distribuição de diferentes mercadorias. Segundo Wallerstein (1996, p. 87, tradução livre), “conceitualmente e historicamente, as cadeias [globais de mercadorias] consistem de uma série de operações [produtivas e comerciais] que possuem a mesma importância que os elos de uma corrente". Essas cadeias, portanto, se referem a uma rede de processos produtivos cujo resultado final é a mercadoria acabada. Essa rede é composta por todas as etapas de sua produção e processos de circulação, desde a concepção da mercadoria final, a geração do insumo que a dá origem, até a manufatura do produto (ou serviço) final como objeto com valor de uso e de troca. Essas

educacional, técnica e cultural da população, como um fim em si mesmo e como meio para potencializar a produção econômica. De fato, para Furtado, eram os aspectos educacional e cultural os únicos capazes de impedir a obsolescência do trabalhador. 
etapas se estendem por diversas regiões da economia mundial capitalista e atravessam as jurisdições estatais, caracterizando uma cadeia global da mercadoria. Em outras palavras, a cadeia global de uma mercadoria é a articulação entre empresas, produtores, vendedores e consumidores, organizações e famílias em processos econômicos que se espalham geograficamente, perpassando fronteiras e povos (Wallerstein \& Hopkins, 1986; Wallerstein,1996; 2001; 2006).

O conceito de cadeia global de mercadorias é útil para a investigação de cada uma das etapas econômicas da produção e distribuição de uma mercadoria. Nossa proposta, porém, requer a investigação das determinações políticas e históricas da cadeia global da mercadoria. Essa proposta aponta para uma investigação que busque encontrar as determinações políticas que moldam a instalação particular das cadeias das mercadorias e que se encontram na esfera da história e, mais particularmente, da tecnologia, da diplomacia, da guerra, da lide jurídica, da corrupção, do engodo, enfim, do poder. Para essa tarefa - identificar padrões de interação política entre os Estados e entre os Estados e as empresas no espaço da diplomacia, das leis, da guerra, do conflito, da acomodação, etc., que sustentam a cadeia global mercadoria - derivaremos o conceito de cadeia global de poder da mercadoria.

A montagem de uma cadeia global de mercadoria engendra a organização dos agentes sociais globais de acordo com as necessidades do bloco social hegemônico. A hegemonia ocorre como bloco social e como processo político e econômico a nível "interno" e "externo". Para um país hegemônico - ou que se pretenda hegemônico -, seguindo Gramsci (2000), a montagem de uma aliança interestatal que se sustente em tempos de paz significa o provimento de recursos aos aliados, bem como concessões políticas de diversas naturezas, em busca de relações privilegiadas com os integrantes do bloco social. Além disso, é necessário que o país hegemônico construa ferramentas que o permitam influenciar a orientação da política externa de outras potências - adversárias ou não -, ao mesmo em que mantém relativamente intacta a orientação autônoma de sua própria. Seguindo essa conceituação, a cadeia global de poder, a fim de proteger a reprodução da acumulação, conta com a instalação de mecanismos de regulação dos preços, de modo a serem utilizados como ferramenta punitiva ou premiadora quando necessário, e também de canais de acumulação de poder, aqueles contatos diplomáticos e bases militares que asseguram a operacionalização do poder a nível do sistema interestatal capitalista.

As cadeias globais de poder, portanto, referem-se justamente às relações políticas estabelecidas pelos agentes político-econômicos de modo a reproduzir alianças estratégicas 
com amigos com o fim de garantir a reprodução da cadeia global de valor da mercadoria, inclusive, quando necessário, exercendo impacto geopolítico e geoeconômico sobre adversários ou grupos sociais cujas demandas ultrapassem os limites concessivos do bloco social hegemônico. Em suma, a cadeia de poder pode consistir em (mas não se limita a) uma rede de alianças militares e diplomáticas, no provimento de recursos bélicos e financeiros e apoio em caso de conflito econômico ou militar, em acordos de proteção militar e diplomática para instalação de bases militares e canais de contato diplomático, na montagem de ferramentas institucionais globais de coerção para constranger a conduta dos outros.

Nossa hipótese é a de que a cadeia de poder da mercadoria, em nosso caso, do petróleo, impacta decisivamente os processos nacionais de subdesenvolvimento. Para verificala, é investigamos as feições históricas da cadeia de poder do petróleo entre os anos 1945 e 1990, para em seguida, observar e discutir de que maneira ela pode ter impactado o processo de subdesenvolvimento da Venezuela no mesmo período.

\section{A cadeia global de poder do petróleo de 1950 a 1980}

A cadeia global de poder do petróleo possuía, grosso modo, seis componentes. Pelo lado dos consumidores, estava a Europa e o Japão com seus projetos de reconstrução pósguerra e retomada capitalista. Pelo lado do fornecimento, estava a Arábia Saudita. A operação produtiva e comercial e a distribuição das rendas extraídas da atividade petrolífera ficavam por conta do cartel de companhias privadas ocidentais. Um sistema de precificação totalmente submetido às produtoras petrolíferas. O capital, a proteção e os valores eram fornecidos pelos Estados Unidos. E o clima de opinião antissoviético permitia projetos nacionais de desenvolvimento e de relativa autodeterminação, desde que nos marcos do capitalismo.

A Segunda Guerra Mundial deixou os principais aparelhos produtivos nacionais sem quaisquer condições de voltar a operar, especialmente aqueles localizados na Europa Ocidental e em partes importantes do Leste Asiático, graças à destruição física e psicológica que se abateu sobre as forças produtivas daquelas e de outras regiões do planeta. Tal situação contrastava diametralmente à dos Estados Unidos na época, situação que, para este país, exigia a construção de uma ordem estável e favorável ao fluxo internacional de bens e capitais. Isso significava concretamente que os Estados Unidos poderiam fomentar diretamente o desenvolvimento e a industrialização de aliados em potencial, exportando-lhes capital, por meio dos planos Marshall e Dodge, bens de produção, alimentos e petróleo, além 
de assistência técnica e vantagens cambiais e comerciais (Serrano, 2004; Eichengreen, 2011; Panitch \& Gindin, 2012).

O sistema interestatal capitalista do pós-guerra se desenvolveu compartilhando o planeta com um "sistema interestatal socialista", cujos valores eram absolutamente incompatíveis entre si. Foi com referência a esse conflito de valores que o presidente Truman conseguiu construir um bloco complexo de valores que orientaram a conduta externa dos Estados Unidos. A partir disso, os Estados Unidos promoveram um compromisso com a negação do imperialismo soviético, garantindo a autonomia e a autodeterminação (de alguns) dos povos e apoiando - desde que sob sua liderança e nos marcos dos arranjos capitalistas projetos nacionais de desenvolvimento econômico (Arrighi, 2012, pp. 69-70).

A formação do bloco social hegemônico requeria o fornecimento seguro de petróleo para a reconstrução do potencial econômico europeu e japonês. Por causa das duas guerras mundiais, haviam ficado claras tanto a importância estratégica do petróleo, quanto a mudança do eixo global de produção do Caribe para o Oriente Médio. Segundo Fuser (2005, p. 98). Por esses motivos, era necessário garantir a presença exclusiva dos Estados Unidos na Arábia Saudita. Como mostra Engdahl (1992, p. 88), os oficiais estadunidenses chegavam o desenvolvimento do petróleo saudita estava intimamente ligado aos interesses nacionais dos Estados Unidos.

A Arábia Saudita passara então a ser uma peça fundamental no tabuleiro da segurança energética para a hegemonia dos Estados Unidos. Logo após o estabelecimento do consórcio ARAMCO, as relações diplomáticas entre Estados Unidos e a Arábia Saudita se aprofundaram de modo crescente, especialmente depois do histórico encontro entre Franklin Roosevelt e Ibn Saud, em 14 de fevereiro de 1945, a bordo de um navio estadunidense (Blanchard, 2008). Para selar a amizade, os Estados Unidos obtiveram autorização para construir uma base aérea em Dammam, com a promessa de prover assistência e treinamento militar ao parceiro árabe. Com efeito, Franklin Roosevelt, após considerar a Arábia Saudita como "vital para a defesa dos Estados Unidos", qualificou o país para um programa de empréstimos e fornecimento de armamentos "que criaram impressões favoráveis na Arábia Saudita e facilitaram o desenvolvimento de relações íntimas após o fim da Segunda Guerra Mundial" (Al-Rasheed, 2010, p. 101, tradução livre). Em suma, "as operações da Aramco e as exportações de petróleo, as contribuições dos EUA para o estabelecimento do sistema financeiro saudita e o envolvimento de agentes dos EUA no desenvolvimento da infraestrutura do Reino foram os pilares cruciais das relações bilaterais econômicas $e$ 
comerciais naquele período" (Blanchard, 2008, p. 4, tradução livre, grifo meu). Pode-se dizer que para incluir a Arábia Saudita no bloco social hegemônico, os Estados Unidos atuaram de modo semelhante em comparação com Europa e Japão, fornecendo materiais e apoio político em troca do fornecimento ininterrupto de petróleo bruto para a reconstrução capitalista.

Outro pilar fundamental da cadeia global de poder do petróleo em sua primeira fase era o esquema produtivo e comercial do óleo bruto. Tal esquema estava assentado nos seguintes elementos: sistema de concessões Estado-empresas, concentração das operações em um cartel e manutenção de preços baixos com garantia da lucratividade. Participaram do cartel as seguintes empresas: Exxon, Mobil, Gulf, Texaco, Chevron, British Petroleum (BP) e Royal-Dutch Shell, que ficaram conhecidas como as Sete Irmãs por sua atuação oligopolista (Van Der Linde, 1991). Essas empresas concluíram o Red Line Agreement (Acordo da Linha Vermelha), em 1928, que consistiu em estabelecer uma região (traçada no mapa com um lápis vermelho) - compreendendo os países árabes do Oriente Médio, menos o Kuwait - em que apenas as empresas signatárias estariam autorizadas a obter concessões (Fuser, 2005). Além do mais, uma signatária apenas poderia contratar com os governos locais se houvesse a participação de outras signatárias, impedindo a ação isolada das corporações. A ideia era fixar limites ao volume de produção, com a intenção de manter os preços baixos - garantindo assim o abastecimento do bloco social hegemônico -, e restrições à participação de empresas menores - garantindo assim a lucratividade do negócio (Van Der Linde, 1991). Tal modelo de determinação da oferta constituiu o esquema produtivo e comercial da cadeia global de poder do petróleo até o fim da década de 1960.

O último pilar fundamental da cadeia global de poder do petróleo era o sistema de precificação do óleo bruto, determinante para o preço dos bens de consumo final e da divisão da renda petrolífera entre empresas e Estados. A partir de 1948, para dar transparência a governos e refinarias, o cartel elabora o sistema de publicação de preços (posted prices), em que primeiro a Mobil operando no Iraque publicou seus preços em 1950, seguida pela Aramco no mesmo ano para o Arabian Light e pela Exxon, na Venezuela, em 1952 (Parra, 2004). Como parte da política empresarial oligopolista de colocar a concorrência sob controle e, com isso, também o volume de oferta e os preços, as grandes corporações possuíam acordos de recompra entre si (Offtake Agreements), que consistiam em que uma empresa que produzisse mais óleo do que necessitava repassava seu "superávit", a um preço menor que o de mercado, a uma empresa que necessitava mais do que produzia, ou seja, era "deficitária". Estes acordos de recompra eram um mecanismo central de domínio do mercado por parte das empresas, por 
meio do qual garantiam barreiras à entrada de novas competidoras, mantinham o controle da oferta e, consequentemente, dos preços a níveis baixos, mantendo sua lucratividade (Van Der Linde, 1991).

Com o recrudescimento da concorrência e dos conflitos, os elos da cadeia de poder do petróleo vieram a sucumbir, um a um, resultando na desorganização temporária dessa cadeia.

Foi a progressiva entrada de novos produtores na oferta mundial de petróleo que exerceu as primeiras pressões sobre a cadeia global de poder do petróleo. Entravam em cena, ainda nos anos 1950, as algumas empresas estadunidenses e europeias independentes e as exportações soviéticas de petróleo. Esse evento fora suficiente para que os preços publicados pelas empresas entrassem em vagarosa mas consistente tendência de deterioração nos anos 1950, disparando descontentamentos dos países produtores, que não tinham qualquer influência sobre os preços e temiam uma diminuição nos repasses petrolíferos para seus orçamentos. As maneiras de aumentar suas rendas eram a renegociação dos contratos de concessão para e o aumento do volume de produção em si (Parra, 2004).

Tais descontentamentos ganham ímpeto com o recrudescimento do nacionalismo petrolífero no final dos anos 1950, principalmente na Venezuela e no Iraque, iniciando a articulação de países exportadores para renegociar contratos de concessão. Um incentivo extra para a articulação dos países produtores foi a continuação da diminuição dos preços publicados pelas empresas, em 1960. Com isso, a onda de tensão e confrontação predominante nos países produtores aumentou. A Venezuela imediatamente tratou de propor a articulação entre eles de modo a criar mecanismos de coordenação da produção por meio de cotas. A resposta positiva veio do Iraque, que convocou Irã, Kuwait, a própria Venezuela e a Arábia Saudita para reunirem-se em Bagdá, no dia 14 de setembro de 1960, para formarem a Organização dos Países Exportadores de Petróleo. O objetivo dos países da OPEP era promover negociações em bloco com o cartel aumentar o repasse de rendas das empresas para os governos (Parra, 2004; McNally, 2017).

Novas condições de mercado apareceram, com o aumento relativo da demanda no fim dos anos 1960, determinando o esgotamento da capacidade ociosa dos Estados Unidos e aumentando a importância relativa do petróleo da OPEP para o suprimento do bloco social hegemônico (McNally, 2017). Conhecendo sua importância para a cadeia do petróleo, os países da OPEP passaram a avançar cada vez mais vorazmente sobre a definição das regras dos contratos, da distribuição das rendas e da determinação dos preços. Com isso, derrubaram 
a predominância do sistema de concessões, substituído pelos acordos isolados de partilha, abatendo parte importante do esquema produtivo da cadeia global do petróleo

Tal esquema ainda fora atacado em duas outras frentes: a dos preços e a da propriedade privada dos ativos produtivos.

Seguindo êxitos da Líbia, os países produtores já haviam começado a reverter a tendência de queda nos preços administrados que predominou nos anos 1960. Mas o marco histórico dessa tendência de alta de preços ocorreu de outubro de 1973 até janeiro de 1974. Em 1973, a escalada de tensões militares em Israel, conhecida como Guerra do Yom Kippur envolvendo Egito e Israel, colocou alguns países petrolíferos do Golfo Pérsico, principalmente a Arábia Saudita, em posição de crítica aos Estados Unidos e aos países consumidores por seu apoio a Israel. Em resposta, dez países árabes petrolíferos concordaram, em 17 de outubro de 1973, em reduzir a produção de petróleo em 5\% por mês enquanto a crise não fosse resolvida. "Em 18 de outubro a Arábia Saudita foi além, anunciando uma redução de $10 \%$ na produção de petróleo, junto a uma proibição completa do carregamento de petróleo para os Estados Unidos" (Al-Rasheed, 2010, p. 132, tradução livre). O resultado foi um aumento colossal nos preços do petróleo em cerca de 300-350\% e uma transferência massiva de renda para os países exportadores de petróleo.

Ainda no fim dos anos 1960, o Iraque escolheu uma estratégia agressiva para renegociar o pagamento de impostos pelas empresas, que consistiu em ameaçar a nacionalização completa. Diante da resistência das grandes corporações em ceder às crescentes demandas do Iraque por maior participação nas rendas, em 1972 o governo nacionalizou completamente a Iraq Petroleum Corporation, garantindo total controle da empresa e dos recursos petrolíferos do país. A Arábia Saudita seguiu uma estratégia menos agressiva, mas com resultados parecidos, adquirindo 22\% das ações da Aramco em 1973 e finalizando o cauteloso processo de nacionalização em 1980. O Irã, após a Revolução de 1979, também não poderia deixar de nacionalizar a concessionária em seu território (Askari, 2013). A Venezuela seguiu a tendência, beneficiada pelo aumento nas rendas petrolíferas, e criou a estatal PDVSA em janeiro de 1976 (Carvalho, 2013).

Essa onda de nacionalizações, nos anos 1970, deu aos países da região a capacidade de determinar os preços, publicados anualmente em uma lista que tinha como referência principal o Arabian Light, óleo bruto produzido pela Arábia Saudita. Com isso, a responsabilidade pela determinação, manutenção e publicação dos preços passou totalmente à 
OPEP e, mais precisamente, à Arábia Saudita, produtora do óleo bruto referencial (marker ou benchmark), principalmente por meio do controle da oferta (Parra, 2004).

Em suma, a essa altura, a cadeia global de poder do petróleo havia sido totalmente desorganizada em seus elementos centrais. A continuidade do fornecimento aos mercados europeus estava duplamente ameaçada com o aumento na demanda global e nos preços do óleo bruto. O esquema produtivo baseado no cartel das Sete Irmãs e no sistema de concessões havia sido subvertido pela onda de nacionalizações e pelos contratos de partilha. E o nacionalismo econômico, que até certo ponto era autorizado pelo bloco social hegemônico, chegou ao ponto de avançar sobre as rendas do cartel e minar sua lucratividade ${ }^{4}$.

A situação problemática da cadeia global de poder do petróleo, porém, viria a ser solucionada já nas décadas de 1970 e 1980, quando foram estabelecidas as bases para sua reorganização. A partir de então, a cadeia do petróleo estaria assentada na diminuição da demanda e dos preços do óleo e na completa financeirização do esquema de comércio e do sistema de precificação.

Por causa dos choques de preços de 1973 e de 1979, os países importadores líquidos iniciaram uma série de projetos de investimento na diversificação de fontes de energia e em tecnologias de conservação e redução do uso. Plantas de geração nuclear iniciaram operação e o gás natural passou a ser utilizado como fonte para geração de energia elétrica na Europa. É também nessa época que tomam força as preocupações com a redução da queima de combustíveis em favor da preservação ambiental.

\begin{abstract}
Graças a essa e outras medidas, pouco mais de uma década depois os Estados Unidos tinham $25 \%$ mais eficiência em combustíveis e $32 \%$ mais eficiência no uso do petróleo do que durante a crise de 1973. [...] Mais importante, a estrutura econômica dos Estados Unidos mudou dramaticamente após os anos 1970, passando a consumir menos da metade por dólar do produto nacional bruto (PNB) do que nos anos 1970. A indústria intensiva em energia diminuiu no país e a relação entre preços energéticos e crescimento diminuiu (Shaffer, 2009, p. 8, tradução livre).
\end{abstract}

A resposta do governo estadunidense a essa desorganização da cadeia do petróleo foi transferir a competição da esfera industrial para a esfera financeira, sobre a qual reorganizara a própria cadeia. Inúmeros eventos (tais como a Guerra ao Vietnã e a política monetária dos Estados Unidos) se associaram ao aumento nos preços do petróleo para gerar uma enorme massa monetária que não mais poderia se reproduzir nos canais industriais tradicionais e só poderiam se reproduzir no sistema financeiro (Arrighi, 2008).

\footnotetext{
${ }^{4}$ A pressão sobre a lucratividade não se abateu apenas sobre as corporações petrolíferas. Toda a lucratividade das economias do G-7, individualmente e em conjunto, experimentou entre, 1965 e 1973, um declínio de mais de $40 \%$ na taxa de retorno (Brenner, 2006, p. 99; Arrighi, 2008, p. 113).
} 
A Arábia Saudita era um dos grandes beneficiários da massa financeira gerada pelos aumentos de preços do petróleo em 1973. Como não poderia utilizar toda a massa de petrodólares em sua economia doméstica teria de redirecioná-la para o setor financeiro privado internacional. Por esse motivo a diplomacia financeira dos Estados Unidos entrou em ação de modo a garantir que os petrodólares seriam reciclados no mercado financeiro internacional, dando o primeiro impulso de "desfibrilação" do sistema monetário do dólar puro que acabara de nascer, mas ainda corria risco de perecer - o segundo impulso viria com o choque de juros de 1981 (Gowan, 1999). Engdahl mostra que já em 1974 o Tesouro dos Estados Unidos “pressionou por um programa de 'reciclagem' para acomodar os elevados preços do petróleo":

O Tesouro dos EUA estabeleceu um acordo secreto com a Agência Monetária Saudita, SAMA [nos termos do qual] uma parte significativa das rendas petrolíferas sauditas seriam investidas no financiamento dos déficits governamentais dos EUA. Um jovem banqueiro radicado em Wall Street, David Muford, em nome da principal firma de eurotítulos de Londres, White Weld \& Co., foi enviado à Arábia Saudita para tornar-se o principal "conselheiro para investimento" da SAMA. Sua incumbência era guiar o investimento dos petrodólares sauditas para os bancos corretos, naturalmente em Londres e Nova Iorque (Engdahl, 1992, p. 137, tradução livre).

Com efeito, segundo dados de Begendahl (1985), em 1973-1974 a OPEP recebeu cerca de US\$110 bilhões em petrodólares, metade dos quais foi utilizada internamente para projetos governamentais de desenvolvimento econômico nacional. Da outra metade, uma quantia significativa de US\$19 bilhões foi direcionada a títulos de curto prazo no mercado bancário internacional, especialmente aquele que se desenvolvia em Londres alheio às regulações financeiras nacionais que os Estados Unidos impunham a seus bancos ${ }^{5}$.

Esses eventos vieram a calhar para as necessidades dos Estados Unidos à época. $\mathrm{O}$ país precisava de um aumento nos preços do petróleo para fortalecer o poder financeiro do setor privado e seu disciplinamento sobre os demais países, de modo a aquietar os crescentes questionamentos colocados por seus aliados. O que ocorreu, portanto, já na década de 1970, foi uma espécie de articulação esforçada da diplomacia dos Estados Unidos para aquietar

\footnotetext{
${ }^{5}$ Nos anos 1960, operava em franca ascensão em Londres uma praça financeira exótica, o chamado mercado de eurodólares. Era um mercado de depósitos e empréstimos em dólar, alheio às regulações financeiras do Reino Unido, como se fosse uma praça offshore na "soberana" City londrina. Era uma "aberração" do sistema financeiro, já que, via de regra, os países não admitem que moeda estrangeira seja depositada ou emprestada em seu território e fora de suas regulações. Via de regra, também, poucos países admitiriam transações livres com sua moeda nacional no território de um país estrangeiro, dadas as dificuldades que essas transações poderiam gerar ao valor cambial de sua moeda. O crescimento do volume dessa praça financeira ocorreu como consequência da expansão monetária efetuada pelos Estados Unidos em contexto de Guerra do Vietnã e combate à crise econômica interna e como consequência da elevação dos preços internacionais do petróleo.
} 
demandas da OPEP e transferir o eixo da cadeia global de poder do petróleo para o sistema financeiro.

Como os países produtores haviam tomado diversas posições importantes na cadeia global de valor do petróleo, ao longo da década de 1970, o bloco social hegemônico abriu mão dessas posições (o elo upstream) e concentrou esforços em transferir a determinação dos preços do petróleo para o disciplinador mercado financeiro, dominado pelo dólar e pelos grandes intermediários estadunidenses. Os Estados Unidos tiraram da OPEP (que, de qualquer maneira, já não conseguia mais se articular, graças às inconciliáveis divergências entre Arábia Saudita e Irã) o poder de estabelecer os preços do petróleo e o repartiram entre o mercado financeiro e a Arábia Saudita, ambos agentes sociais suficientemente sob o controle restrito de Nova Iorque e Washington.

A Arábia Saudita passou a adotar o sistema de precificação chamado netback ${ }^{6}$, com o qual desarmou de vez a já precária articulação na OPEP, já que não precisava mais obedecer às cotas estabelecidas pelo grupo. O sistema teve o efeito de livrar a Arábia Saudita dos compromissos de manter o preço dos diferentes petróleos brutos da OPEP e desarmar de vez qualquer possibilidade de articulação do grupo. O sistema de netback, porém não durou muito, pois exigia a compra de grandes volumes, em época de baixa demanda por refinados, levando muitas refinarias à falência. Para complicar ainda mais a situação, na metade dos anos 1980, foi lançado um contrato de compra e venda de um petróleo bruto chamado "Brent15 dias"7.

A segunda metade dos anos 1980, portanto, eliminou de uma vez por todas os preços publicados e colocou os preços do petróleo totalmente sob controle das flutuações de mercado, especialmente o mercado à vista - no caso do Arabian Light -, mas também, crescentemente, o mercado de futuros - no caso do contrato do Brent-15 dias. A Arábia Saudita, na tentativa de promover uma corrida competitiva para regular a produção, aderiu ao Brent como referencial para determinar seus preços, substituindo o princípio do netback, colocando todo o petróleo mundial sob o controle do que ocorria com o mercado de futuros no contrato do óleo Brent (Carollo, 2012). O contrato Brent-15 dias era lançado pelas empresas donas do óleo (Shell, BP, Exxon e Chevron) no fim dos anos 1980. O contrato dava a seu proprietário o direito de receber um carregamento de óleo seis meses após sua emissão e

\footnotetext{
${ }^{6}$ Com o sistema netback, os preços do óleo Arabian Light, qualidade vendida pela Arábia Saudita, eram definidos de acordo com o preço de venda dos refinados.

${ }^{7} \mathrm{O}$ óleo Brent era uma qualidade gerada nas bacias do Mar do Norte, quando Reino Unido e Noruega passaram atuar como importantes produtores exportadores dessa qualidade no mercado mundial.
} 
mudava de proprietário milhares de vezes ao longo desses seis meses, o que provocava oscilações no preço do contrato e, consequentemente, do petróleo bruto em si. Essas características tinham o objetivo - atingido com êxito - de desligar completamente o óleo Brent do controle da OPEP (Idem, 2012).

Após uma reformulação, o contrato para o óleo Brent adquiriu as características que possui no início do século XXI. No novo contrato Brent, (i) o volume do carregamento era bem menor, apenas 1000 barris; (ii) não havia qualquer intenção ou necessidade de entrega física do lote; (iii) a transação era intermediada pela Bolsa Internacional de Petróleo e os preços de compra e venda eram estabelecidos por seus analistas ${ }^{8}$. Foi exatamente essa nova dinâmica que provocou uma revolução do mercado internacional de petróleo. A Bolsa Internacional de Petróleo e os contratos nela negociados eram facilmente acessíveis inclusive por agentes comumente alheios ao negócio petrolíferos, tais como bancos, companhias de seguro e outras instituições financeiras. Com efeito, no século XXI essas são as principais instituições atuantes nesse mercado, operando-o como mero mecanismo financeiro de gestão da liquidez, completamente independente das dinâmicas do mercado petrolífero (Idem).

Como consequência, os preços do petróleo tornaram-se indicadores completamente fictícios consistindo em meras estimativas baseadas nos índices diários do mercado financeiro. É o índice da Bolsa Internacional do Petróleo ${ }^{9}$ que indica o valor contrato quinzenal do Brent, que por sua vez influencia o valor do Brent Datado, que por sua vez baseia todos os outros preços mundiais do petróleo bruto. Quando, em 1988 e novamente em 2002, os países da OPEP adotaram o Brent como referencial, com o objetivo de colocar os países do Mar do Norte sob sua influência, o que ocorreu na verdade foi o contrário: a OPEP entrou completamente na órbita e disciplina do mercado financeiro, com lógica própria e não subordinada ou subordinável diretamente às orientações da articulação no âmbito da OPEP (Idem, p. 102).

\section{Rentismo petroleiro e desenvolvimento difícil na Venezuela}

\footnotetext{
${ }^{8}$ A Bolsa Internacional de Petróleo (IPE - International Petroleum Exchange) foi criada em 1988 para funcionar como uma grande feira intermediadora de contratos puramente financeiros referentes ao óleo Brent. Os objetivos da bolsa eram massificar e popularizar o volume de negócios dos instrumentos financeiros relacionados ao petróleo.

9 Atualmente, as três principais bolsas de negociação de petróleo são a NYMEX em Nova Iorque, a ICE (Intercontinental Exchange) em Londres - que incorporou a IPE - e a TOCOM (Tokio Commodity Exchange).
} 
Para o caso da Venezuela, o comportamento rentista associou-se à crescente dependência em relação à produção e exportação de petróleo (Astorga, 2003). À medida que o século XX avançava em suas primeiras décadas, o petróleo foi se tornando produto com viabilidade comercial para a Venezuela e deslocando o cacau e o café da pauta exportadora do país, com o primeiro poço exitoso perfurado em 1914. Assim, o país passou a crescer mais rapidamente e chegou a "tonar-se, a partir do final da década de 1920, o segundo maior produtor mundial de petróleo" (Lucena, 2008, p. 60). Com efeito, a produção do óleo saltou de cerca de 1 milhão de barris por ano, em 1921, para cerca de 135 milhões em 1927, um crescimento vertiginoso que puxou a expansão econômica e o emprego e deu o ponta pé inicial para a dependência nacional do petróleo (ibid., idem).

A dependência do petróleo cobrou seus custos na década de 1940, quando em razão da Segunda Guerra Mundial uma retração no comércio internacional derrubou a venda do petróleo venezuelano de 180 milhões de barris, em 1939, para 157 milhões em 1940. Os efeitos foram sentidos na capacidade importadora do país que, somado ao baixo desenvolvimento industrial do país na época, resultou em escassez de manufaturados, inflação e, em última instância, uma retração de 10\% no PIB e 12\% do PIB per capita em 1940, uma crise que perdurou até 1944.

Porém, foram as dificuldades econômicas durante a guerra que impulsionaram reformas importantes no país. Reformas institucionais no aparelho de Estado - sob o governo de Medina Angarita (1941-1945) - estabeleceram a cobrança do imposto sobre a renda das empresas petrolíferas, para melhorar a arrecadação governamental. Além disso, foi no governo de Angarita que a regulação petrolífera mais importante para a Venezuela até a década de 1970 entrou em vigência, com a Lei de Hidrocarbonetos (Ley de Hidrocarburos) de 1943. "Com essa lei, o Estado venezuelano aumentou sua quota nos lucros da exploração petrolífera, incluindo royalties estatais que passariam de 15\% para 16,6\%" (Lucena, 2008, p. 66). Essas reformas se inseriram no contexto de disputa pela renda petrolífera para que pudesse ser alocada pelo governo em um esforço nacional de industrialização, de modo que a própria dependência do petróleo diminuísse progressivamente e a produção de riqueza do país se estabilizasse. Assim apareceu o entendimento de que o petróleo deveria ser utilizado para fomentar medidas que dessem vigor aos esforços de industrialização (Astorga, 2003, p. 646). Esse entendimento deu origem a um tipo de coordenação política do desenvolvimento econômico que visou promover a industrialização via substituição de importações, seguindo 
caminho semelhante ao dos demais países da região, tal como sugerido pela Comissão Econômica para o Desenvolvimento da América Latina - CEPAL.

Na transição da década de 1940 para a de 1950 a Venezuela entrou em um conturbado contexto político, com trocas sucessivas na presidência operadas via golpes militares. Nesse período, um novo passo foi dado na consolidação da dependência petrolífera quando o então presidente Rómulo Gallegos (1948) reformou a regulamentação de tributação sobre a renda do petróleo, estabelecendo a divisão igualitária entre as empresas e o governo. A medida ficou conhecida como fifty-fifty e irrigou ainda mais o orçamento governamental em época de preferência pelo financiamento público do desenvolvimento.

Com efeito, o rápido desenvolvimento da atividade petrolífera na Venezuela viabilizou transformações igualmente aceleradas no país, principalmente no que se refere aos indicadores sociais. Embora a riqueza petrolífera não houvesse sido imediatamente percebida pela população no início, logo na década de 1930 o país havia conquistado avanços significativos na área da saúde, quadruplicado o produto interno per capita em relação ao início do século e melhorado a alfabetização da população acima de 15 anos de idade. Os recursos do petróleo foram essenciais para a

\footnotetext{
transição de uma economia agrário-exportadora para uma economia mineral-exportadora. Os recursos econômicos do Estado aumentaram consideravelmente pelas exportações petrolíferas, que passaram de 46,6\% das exportações totais, em 1925, para 86,1\% em 1935. Observa-se que esse percentual permaneceu praticamente o mesmo até 1960. Após, a participação do petróleo nas exportações totais ultrapassou 90\% [...] (Lucena, 2008, p. 81).
}

Além disso, na segunda metade da década de 1940, as rendas petrolíferas permitiram ao país efetuar investimentos no desenvolvimento industrial que o auxiliaram a crescer aceleradamente até o fim da década de 1970. Esses esforços de industrialização tinham o objetivo de diminuir a volatilidade da riqueza do país em resposta à volatilidade dos preços do petróleo. Paradoxalmente, no entanto, a dependência das exportações para aquisição de divisas e para o financiamento dos investimentos apenas fez aprofundar a dependência petroleira, além de ter acarretado distorções no próprio processo de industrialização do país.

A substituição de importações gerou resultados particulares à Venezuela, graças ao câmbio valorizado e alto grau de importações (devido à abundância de divisas), nasceu uma indústria pouco competitiva externamente e na qual a substituição não foi completa. Ademais, a indústria era excessivamente dependente das exportações - tanto pelo fato de que o alto grau de importações aplacava o mercado interno quanto pelo fato de que dependia das divisas geradas pela exportação do petróleo para adquirir bens de capital (Jeannot, 2010) 
Antes da política de substituição de importações, contudo, a industrialização no país já vinha sendo puxada pelos investimentos na exploração e produção de petróleo, desde a década de 1920. O petróleo já começava a dar resultados positivos à Venezuela, apesar das distorções, resultados que se acentuaram durante a Segunda Guerra Mundial. O aumento da demanda pelo óleo, gerado pela guerra, refletiu-se em um crescimento do produto de $40 \%$ em 1944, 20\% em 1946 e 10\% em 1948 (Lucena, 2008). O governo de Rómulo Betancourt na segunda metade da década de 1940 (Betancourt voltou à presidência na década de 1960) começava a plantar as bases para possibilitar um desenvolvimento capitalista no país, com a criação de um mercado interno por meio da expansão das relações de assalariamento e consequente monetização da economia, a criação da Corporação Venezuelana de Fomento $(\mathrm{CFV})$ e a aplicação de recursos petrolíferos à agroindústria, para produção de bens alimentícios básicos (Melcher, 1995).

O início da década de 1950 apresenta crescimento irregular no PIB da Venezuela, mostrando indicadores de dois dígitos em alguns anos e próximos de zero em outros, simultaneamente a grande instabilidade política. De toda maneira, essa é considerada a época do "grande salto econômico", em que as rendas do petróleo permaneceram em trajetória de elevação, permitindo um programa de expansão do investimento público ${ }^{10}$. Durante o governo ditatorial de Pérez Jiménez (1952-1958), uma série de reformas foi levada a cabo, envolvendo o serviço educacional e de saúde promovidos pelo Estado, bem como o setor de infraestrutura, com a construção de prédios públicos, hotéis, pontes, estradas e universidades (Lucena, 2008, pp. 69-70). De fato, a melhoria da infraestrutura por meio do gasto público foi a prioridade daquele governo. Além disso, o Estado sustentou diretamente o desenvolvimento da indústria básica, da siderurgia, petroquímica e o setor de energia elétrica, bem como promoveu inúmeras alterações alfandegárias como medidas de proteção da indústria nacional.

$\mathrm{O}$ incipiente processo de industrialização, a despeito de bem-sucedido em aumentar sua participação na produção doméstica, já mostrava as contradições que perduraram até seu fim. Essas contradições eram causadas pela própria abundância da renda petrolífera. Por um lado, ela provia as divisas demandadas pelo processo de industrialização (importação de bens de capital) e irrigavam a renda nacional, permitindo a existência de alguma demanda interna (Lucas, 2006). Por outro, no entanto, sustentavam a valorização do bolívar frente ao dólar e

\footnotetext{
${ }^{10}$ A entrada da década de 1950 trouxe os esforços mais notáveis de promoção da industrialização venezuelana. As mencionadas reformas da década de 1940 não engendraram um esforço sistemático de industrialização, embora tenham promovido as condições para que isso acontecesse posteriormente: "Essas [..] condições [...] fizeram possível a passagem ao estabelecimento de indústrias no país, processo que realmente se inicia a partir dos anos 50" (Melcher, 1995, p. 69, tradução livre).
} 
facilitavam a importação de bens manufaturados, contrapondo a política governamental de proteção aduaneira e deteriorando a competitividade dos produtos nacionais. Essas contradições causadas pela abundância do petróleo produziram um processo de industrialização que, a despeito de ter dado resultados positivos, gerou uma indústria frágil e pouco integrada, acarretando o que Carvalho (2013) chamou de desenvolvimento difícil.

O fim da década de 1950, em meio a instabilidade política e sucessivas interrupções de governos, viu a institucionalização dos esforços de industrialização incentivada pelo Estado via substituição de importações. $\mathrm{Na}$ época, o ambiente nacional era amplamente favorável à planificação econômica e industrial, especialmente por influência da linha teórica difundida pela CEPAL à época. Isso se refletiu na oficialização da substituição de importações e na criação e atuação do Escritório Central de Coordenação e Planificação - CORDIPLAN - da Venezuela, criada em dezembro de 1958 e encarregada de elaborar o planejamento industrial. No primeiro plano quatrienal a instituição estabeleceu metas de crescimento para a indústria, com o objetivo de aumentar a produtividade e a eficiência, bem como de atualização de negócios artesanais em processos fabris modernos. Além do mais, a "ação industrial direta do Estado, durante o Plano Quatrienal (1960-1964), estava direcionada à rápida construção da petroquímica, a siderurgia, diques e estaleiros [...]” (Lucas, 2006, p. 89, tradução livre).

Por meio do decreto 173 de 1958, o governo provisório estabeleceu as bases do processo ao conceder direitos de importações de maquinário, matéria prima e outros utensílios que fossem necessários. Um consenso envolvendo os setores público e privado foi forjado em favor da proteção à indústria nacional, tanto por meio de impostos aduaneiros quanto por meio da preferência à "producción criolla" (produção nacional) nas compras governamentais. As medidas consistiram basicamente na elevação de impostos às importações aliadas a permissões específicas para importação de bens de capital que não fossem produzidos nacionalmente. Até o fim da década de 1950, a proteção aduaneira concentrou-se na indústria de bens de consumo básico, como cigarros, derivados do leite, móveis, etc.

A seguir, à metade da década de 1960, as proteções foram estendidas ao setor industrial intermediário, convergindo com a evolução da política de substituição de importações, em que foram beneficiados os setores de produtos metálicos e químicos, com alguns bens de consumo mais elaborados.

Concretamente, o governo nacional aplicou as seguintes medidas: 1) Proteção aduaneira contra a concorrência estrangeira. 2) Isenção de impostos aduaneiros para matérias primas e bens de capital destinados à indústria. 3) Financiamento industrial a baixo custo. 4) promoção direta, por parte do Estado, para algumas indústrias, como a siderurgia e a petroquímica [...]. 5) Subsídios diretos a algumas indústrias, 
como a leiteira. 6) Assistência técnica à indústria” (Lucas, 2006, p. 72, tradução livre).

O Ministério de Fomento afirmou diversas vezes que os objetivos dessa política de industrialização eram melhorar as condições de vida da população através da distribuição de renda, diversificar as fontes de postos de trabalho, promover a liberação da dependência petroleira e, com isso, possibilitar um desenvolvimento econômico autônomo rumo a uma maior independência nacional.

À metade da década de 1960, o processo de industrialização via substituição de importações já havia surtido efeitos, elevando o crescimento da indústria ao patamar de $5 \%$ anuais, mas também dava sinais de esgotamento, dada sua ênfase no mercado interno, que pouco a pouco chegava a um ponto de saturação. Por isso era necessário avançar a uma nova fase do processo de industrialização. Na nova fase foi diagnosticado que a substituição de bens de consumo estava prestes a se completar e que deveriam ser iniciados os incentivos à substituição de bens intermediários, bem como uma mudança na política de exportações do país que pudesse retirar esses bens do mercado interno.

Nesse sentido, a política de comércio exterior e exportações avançada pelo governo, por meio do decreto $\mathrm{N}^{\mathrm{o}} 803$ de 1967, fazia parte da atualização da política de substituição de importações. Além disso, chegava oportunamente em contexto em que, por um lado a indústria de exportação do país encontrava dificuldades de concorrência no mercado externo, devido a aumentos nos custos de produção e, por outro, a indústria voltada para o mercado interno gerava crescentes demandas de meios de pagamento para importar seus insumos e bens de capital. Nos marcos dessa nova política industrial, os objetivos eram apoiar as indústrias de exportação, especialmente para a geração de divisas, privilegiar indústrias que poupassem divisas e cujos produtos pudessem concorrer em qualidade com os rivais estrangeiros. A necessidade de atualizar a política industrial do país, inserindo a o incentivo às exportações, originou o Plano Quatrienal de 1971. Além das medidas para o incentivo à diversificação das exportações, o Plano Quatrienal buscou promover um processo de descentralização industrial, mais isenções de tributos de importações e a aplicação de controles de qualidade. As medidas de renovação da política industrial faziam parte do programa governamental "Gran Venezuela" (Grande Venezuela), que utilizou o aumento dos preços do petróleo no início da década de 1970 para promover expansão fiscal, elevando a demanda agregada e os investimentos estatais, especificamente no setor petroquímico e metalúrgico. Os resultados imediatos do programa foram a estatização das empresas de produção de petróleo e ferro e o aumento do consumo dos bens industriais nacionais, bem 
como "o crescimento do Produto Interno Manufatureiro a uma taxa média de 8,6\% entre 1974 e 1978, chegando a representar 15\% do Produto Interno Bruto. A ocupação industrial cresceu até alcançar em 1978428.000 empregos” (Lucas, 2006, p. 130, tradução livre).

Em perspectiva mais ampla, é possível observar resultados significativos tanto para o desenvolvimento industrial quanto para a Venezuela em geral. Como mostram os dados compilados por Lucas (2006), entre 1945 e 1957 a indústria nacional cresceu a uma taxa anual média de 12\%, chegando a representar 11\% do PIB em 1958. Já no período entre 1958 e 1973, a indústria nacional cresceu em média $7 \%$ ao ano, atingindo $14 \%$ de participação no PIB da Venezuela. "Também é necessário ressaltar que a produtividade do trabalho se incrementou durante o período analisado [1958-1973], dado que o crescimento da ocupação foi inferior à taxa de crescimento do produto" (Lucas, 2006, p. 125, tradução livre). O aumento na produtividade também é notado por Lucena (2008), que acrescenta os êxitos para a indústria de transformação e para o setor de serviços, que tiveram os seguintes efeitos: "Houve aumento do bem-estar na Venezuela, pela expansão do salário real, que se refletiu na melhoria da qualidade de vida. Em suma, o país viveu um longo período em que se pôde observar tanto uma tendência para o crescimento, como uma tendência para melhorar os níveis de bem-estar da população venezuelana" (Lucena, 2008, p. 86).

Mas apesar dos esforços de industrialização levados a cabo até os anos 1970 e das conquistas socioeconômicas, o país não conseguia estabilizar suas taxas de crescimento, que continuavam associadas à exportação de petróleo. É o que se verifica na passagem da década de 1960 para a de 1970, havendo o produto interno bruto do país crescido 3,2\% em 1969 e 5,9\% em 1970; mas expandindo-se em apenas 0,8\% em 1971 e 0,2\% em 1972. Além disso, a indústria, como já dissemos, não conseguiu inserir-se competitivamente no mercado internacional - graças ao bolívar valorizado - de modo que pudesse diversificar a pauta exportadora do país, nem promover a substituição completa das importações, restando um parque industrial fragilizado e pouco integrado ${ }^{11}$.

Acrescente-se que os programas de expansão fiscal da década de 1970, possibilitados pelo aumento substancial nos ingressos petrolíferos, trouxeram efeitos adversos, como o aumento da dívida externa, que chegou a representar 40\% do PIB da Venezuela em 1978 e a

\footnotetext{
11 “O processo de substituição de importações [na Venezuela], de tendência horizontal (substituição praticamente limitada ao nível dos bens de consumo), esgotou em tempo relativamente breve as oportunidades de aproveitamento do mercado interno e encontrou duas fronteiras de difícil acesso: a das exportações e a da produção de bens intermediários e de capital” (Zavala, 1987, p. 51, tradução livre, grifo no original).
} 
explosão da inflação ${ }^{12}$. Isso significou uma forte retração de quase $3 \%$ no PIB per capita do país na entrada da década de 1980, iniciando um período dramático de ajustes recessivos com quedas repetidas na renda per capita que perdurou pelas décadas seguintes (Lucena, 2008).

Por causa dessas dificuldades que já se afiguravam no fim da década de 1970, o governo Herrera Campíns (1979-1983) foi constrangido a iniciar uma época de ajuste econômico com austeridade fiscal, contração dos gastos públicos e aumento de impostos alfandegários. As principais medidas envolveram também, a princípio, a extinção de controles de preços e a introdução de controles cambiais, graças ao esgotamento do mercado interno e à fuga de capitais, culminando no reconhecimento definitivo de que a Venezuela havia entrado em forte crise econômica no dia 18 de fevereiro de 1983, que ficou conhecido como a "sextafeira negra". Quando o governo tentou reverter a política econômica contracionista, a crise da dívida mexicana agravou os problemas de endividamento externo em todos os países da América Latina.

$\mathrm{Na}$ Venezuela isso se traduziu também em contração do PIB, que retrocedeu 4,5\% em 1980, $2 \%$ em 1981 e $6 \%$ em 1983, além de haver restringido o fluxo de investimentos para o país e aguçado a fuga de capitais, provocando problemas no balanço de pagamentos e desvalorizações cambiais, as quais o governo tentou limitar com os mencionados controles de câmbio. "Ao término do governo Herrera Campíns, o país encontrava-se isolado financeiramente; encerraram-se as possibilidades de obtenção de novos créditos, inclusive para importação de insumos industriais. Cabe mencionar que o setor industrial foi o mais afetado pelas políticas econômicas, o que elevou a taxa de desemprego de 5,4\% em 1979 para 7,8\% em 1983” (Lucena, 2008, pp. 94-5).

Por esses motivos, a dívida pública tornou-se o principal problema para o país na segunda metade dos anos 1980 o que se refletiu na prioridade que o governo Jaime Lusinchi (1984-1988) concedeu às renegociações da dívida pública, como a de 1986, que amenizou o peso dos juros e do principal sobre o orçamento público. Além disso, o governo retoma medidas de ajuste econômico com o objetivo de diminuir o déficit orçamentário deixado pelos programas de investimento da década de 1970 e aplacar o crescimento da dívida externa. Porém, em 1986, o contexto de endividamento, fuga de capitais e escassez de poupança externa somou-se à queda nas receitas petrolíferas para gerar uma grave perda de reservas

\footnotetext{
${ }^{12}$ Cano (2002, p. 99) afirma que há confirmação oficial de que uma quantia imensa (cerca de US\$40 bilhões) de endividamento extra foi contratada na década de 1970, na esteira dos programas de expansão do investimento na indústria básica, que teria sido utilizado para o financiamento de atividades criminosas por empresas e indivíduos da Venezuela, sem que a quantia sequer houvesse circulado pelos bancos do país, agravando a situação cambial e do balanço de pagamentos.
} 
internacionais, que passaram de US\$11 bilhões em 1986 para US\$7 bilhões em 1988, das quais o país não podia prescindir em momentos de baixa dos preços do petróleo. "Com a substancial redução das reservas internacionais, a situação tornou-se preocupante, pois aumentou a vulnerabilidade externa da economia, ficando a Venezuela cada vez mais dependente das exportações de petróleo" (ibid., p. 97).

O governo Lusinchi ainda buscou reverter a depressão econômica com estímulos econômicos via aumento dos gastos públicos. A crise de endividamento, porém, fez com que entre 1980 e 1988 a Venezuela tivesse crescido apenas 0,7\%, atirando o país em situação praticamente falimentar, com crescimento da pobreza, da dificuldade cambial e da inflação, com o já mencionado endividamento externo (ibid., p. 98).

\begin{abstract}
Os indicadores sociais confirmam as profundas marcas sociais da crise: entre $1980 \mathrm{e}$ 1990 o desemprego aberto sobe de $6 \%$ para $11 \%$ e a informalização de $35,4 \%$ para 41,8\%; o salário médio real em 1990 equivalia a 49,8\% do de 1978. Com isso, os níveis de pobreza e indigência da população entre 1981 e 1990 atingiram cifras inusitadas: a porcentagem dos domicílios cujas famílias se encontravam abaixo da linha de pobreza sobe de 22 para 34 e a dos abaixo da de indigência, de 7 para 12. Os $20 \%$ mais pobres da população urbana que em 1981 recebiam $6,9 \%$ da renda total passaram a receber $5,7 \%$ em 1990 e os $20 \%$ mais ricos sobem sua fração de $37,8 \%$ para $44,6 \%$ (Cano, 2002, p. 102).
\end{abstract}

Acompanhando a crise econômica, a situação política e social deteriorou-se gravemente na passagem dos anos 1980 para 1990. O regime político que vigorava desde o fim dos anos 1950, o Pacto de Punto Fijo, dava sinais de desgaste irreparável, sinalizando a importância do momento como ponto de transição ${ }^{13}$. Durante a presidência de Carlos Andrés Pérez (1989-1993), o descontentamento popular recrudesceu, na esteira das medidas de "choque econômico" adotadas pelo governo como estratégia de combate à crise venezuelana na época. O choque envolveu o aprofundamento do ajuste estrutural sob o slogan de "Gran Viraje" (Grande Virada), incluindo corte de gastos públicos e drástica mudança no perfil do Estado. Como sintetizou Lucas (2006, p. 173, tradução livre), “um dos objetivos da nova política consistia em reduzir o papel econômico do Estado e atribuir ao mercado o papel fundamental da alocação dos recursos", sendo assim imprescindível eliminar os controles de preços exercidos principalmente sobre o setor energético, sobre o câmbio e juros.

\footnotetext{
${ }^{13}$ A série de golpes de Estado e a instabilidade política na Venezuela dos anos 1950 foi cessada com o Pacto de Punto Fijo, de 1961. Esse regime concertado em Punto Fijo (cidade ao norte da Venezuela) promoveu a participação institucional privilegiada de dois partidos, a Ação democrática (AD) e o Comitê de Organização Política Eleitoral Independente (COPEI). Na prática a forte limitação do número de atores participantes, a incapacidade de gerar novos quadros e novas lideranças e a corrupção endêmica davam ao regime cara de arranjo oligárquico em vez de concerto democrático. A rigidez do regime obteve êxito em estabilizar o país politicamente, porém impediu o surgimento de novas lideranças e inovações em época de crie. $\mathrm{O}$ regime entrou em colapso seguindo a economia nacional, nos anos 1990 (Azeredo, 2003).
} 
O resultado imediato foi uma desvalorização do bolívar e o aumento de preços da eletricidade, gasolina e água que foram o estopim para o acirramento da tensão social. Como a situação de pobreza já era aguda no país, associada a um quadro de escassez de alimentos e bens de primeira necessidade, a população, em 1989, começara a demonstrar insatisfação de forma violenta, especialmente após o súbito aumento das tarifas de transporte em 27 de fevereiro. Nesse dia, iniciou-se uma onda de protestos populares que abateram toda a cidade de Caracas e continuaram pelo dia 28 de fevereiro, com saques, veículos incendiados e invasão de lojas e supermercados. Como lembra Azeredo (2003, p. 118), a "repressão foi brutal, tanto pela gravidade do conflito, quanto pela inexperiência das tropas em lidar com esse tipo de perturbação. Segundo a estatística oficial, houve 372 vítimas oficiais”. O dia 28 de fevereiro de 1989 é lembrado, por esse fato, como o Caracazo, mas não é o único em que protestos resultaram em violência.

Em junho de 1990, protestos violentos foram realizados contra o aumento dos preços da gasolina; em março de 1991, dois estudantes morreram em confronto com a polícia em Caracas durante protestos contra os altos custos de vida; em novembro de 1991, a polícia matou três pessoas em Caracas durante um protesto; e em dezembro de 1991, as aulas nas universidades e em escolas de nível médio foram suspensas como resultado de protestos que deixaram dez jovens manifestantes mortos nas mãos da polícia. Em janeiro de 1992, novas manifestações tomaram a Venezuela pedindo a deposição do presidente Pérez do cargo (Tarver \& Frederick, 2005, pp. 142-3, tradução livre).

$\mathrm{Na}$ esteira desses eventos e de duas tentativas fracassadas de golpe militar em 1992, o presidente Pérez viu deteriorar-se toda sua sustentação política e passou a ser acusado de irregularidade na gestão de recursos governamentais. Assim, uma coalisão de opositores apoiou a instauração de um processo contra o presidente na corte suprema em 1992. Em maio de 1993 a suprema corte autorizou a instalação de julgamento contra o presidente, julgamento efetuado pelo Congresso em 21 de maio de 1993, sob a acusação de corrupção, culminando no impedimento do mandato presidencial de Pérez (ibid.).

\section{Subdesenvolvimento em perspectiva integrada}

Vimos propondo que é nas condições específicas de cada um dos momentos históricos da cadeia global de poder do petróleo que a trajetória de subdesenvolvimento dos países produtores de petróleo e, especificamente, de nosso objeto de estudo, a Venezuela, deve ser encaixada. A cadeia global do petróleo passou, grosso modo, por três momentos: um de montagem dos elos da cadeia em torno dos Estados Unidos, da Europa, da Arábia Saudita e do cartel de empresas privadas; um de recrudescimento da competição e dos conflitos 
distributivos na cadeia, com sua desorganização; e o último de reorganização sobre bases financeirizadas.

No primeiro momento, entre o fim da Segunda Guerra Mundial e o fim dos anos 1980, a estratégia de combate à superpotência soviética, adotada pelos Estados Unidos, envolvia a propagação mundial de um conjunto de valores, com feições liberais, que facilitaram a adoção de posições mais intransigentes dos países produtores de petróleo frente às corporações do cartel. Outro valor aceito e propagado neste primeiro momento pela potência hegemônica no sistema interestatal capitalista, segundo Arrighi (2012), era uma postura anticolonialista que via com maus olhos qualquer resquício de ingerência estrangeira em determinações internas aos países, fornecendo as bases ideológicas para os países avançarem sobre as rendas e mesmo sobre a propriedade das empresas petrolíferas. Essa postura começou a se intensificar a partir de 1959, com os golpes de Estado no Iraque e na Venezuela, mas tomou ainda mais força logo depois disso, com a criação da OPEP e a tomada definitiva da propriedade petrolífera em favor do controle estatal dessas unidades de produção.

O resultado foi a crescente irrigação dos orçamentos nacionais dos países petrolíferos para o financiamento de seus projetos nacionais de desenvolvimento. Particularmente, a Venezuela estava sob plena influência das orientações da Comissão Econômica para a América Latina e o Caribe - CEPAL -, das Nações Unidas, que sugeriam a diversificação da estrutura econômica como forme de amenizar os efeitos da volatilidade do comércio de commodities sobre o balanço de pagamentos e sobre a renda nacional em geral. O país institucionalizou a política de substituição de importações, ainda que em bases precárias, e buscou pelas vias que pôde o fortalecimento da indústria nacional.

O segundo momento, na passagem da década de 1960 para a de 1970, o recrudescimento das pressões competitivas e dos conflitos distributivos desmontou totalmente a cadeia do petróleo tal como havia sido montada no momento anterior. Os projetos nacionais de autonomia e desenvolvimento dos países petrolíferos evoluíram para um forte nacionalismo que avançou sobre as rendas e sobre os próprios ativos produtivos do cartel petrolífero. Um a um, os elos da cadeia global de poder do petróleo vieram a sucumbir: o esquema de monopólio e concessões privadas, o sistema de preços, a distribuição das rendas e a lucratividade. Os agentes diretos dessa destruição foram os países petrolíferos, organizados em torno da OPEP, foram os principais beneficiários. Seus orçamentos se avolumaram com petrodólares e os projetos nacionais de desenvolvimento e autonomia obtiveram um financiamento exorbitante. 
Nesse contexto, a Venezuela promovia a expansão fiscal e a atualização de sua política industrial com o programa Gran Venezuela. Como vimos, o país experimentou aumento da demanda agregada, e o crescimento do produto industrial a uma taxa média de 8,6\% entre 1974 e 1978, atingindo resultados significativos em crescimento econômico e melhoria da indústria.

No terceiro momento histórico da cadeia global do petróleo, iniciado aproximadamente em 1982 e vigente até o início do século XXI, predominou a submissão dos projetos governamentais à dinâmica autônoma do mercado. O mercado financeiro seria capaz de fazer o que a indústria petrolífera não fez: impedir que os países produtores se apossassem do controle do destino da cadeia global do petróleo e, consequentemente, do bloco social hegemônico. Evidentemente, o mercado financeiro a partir da década de 1970 só poderia ser predominantemente composto por liquidações em dólar, já que os bancos e títulos estadunidenses estavam em posição de vantagem nos anos 1980 tão grande quanto a posição das empresas petrolíferas nos anos 1940. Uma série de desregulamentações e inovações financeiras, especialmente no mercado europeu de dólares, jogou o controle do preço internacional do petróleo nas mãos das bolsas de negócios petrolíferos, submetendo completamente o poder da OPEP de determinar os preços dessa commodity. Além disso, as orientações predominantes passaram ser aquelas originadas em Chicago - em contraposição ao momento histórico anterior, em que predominavam as orientações ideacionais de Bretton Woods -, ou seja, o progresso econômico só poderia ocorrer se submetido completamente às determinações do setor privado.

Com essas alterações, os países produtores de petróleo não seriam jamais capazes de contrapor os interesses do mercado de finanças como foram em relação à indústria petrolífera. Suas condições de atuar em contraposição ao mercado mundial de contratos financeiros petrolíferos são completamente desfavoráveis, especialmente diante da incapacidade de articulação conjunta da OPEP. Após essas alterações, os preços do petróleo entraram em tendência de queda, agravando os problemas cambiais e de endividamento externo da Venezuela, retirando a sustentação petrolífera do país, provocando crises econômica e política insanáveis e ferindo de morte as já precárias experiências desenvolvimentista e democrática venezuelanas.

\section{Considerações finais}


Este trabalho procurou avançar a hipótese de que o processo de subdesenvolvimento da Venezuela esteve profundamente ligado à cadeia global de poder do petróleo, isto é, aos eventos políticos que ocorriam no ambiente internacional. Essa hipótese possui a implicação de que tanto os projetos nacionais de desenvolvimento quanto os estudos acerca dos processos de desenvolvimento e subdesenvolvimento devem necessariamente levar em consideração os eventos políticos da economia mundial capitalista, do contrário correndo o risco de negligenciar variáveis que podem definir o êxito ou $\mathrm{o}$ fracasso do processo de desenvolvimento. Para essa investigação, delineamos o conceito de cadeia global de poder da mercadoria, que pode ser útil exatamente para encontrar as determinações políticas e históricas da produção e circulação das mercadorias.

Verificamos que a Venezuela é um caso típico de subdesenvolvimento, em que a geração do excedente utilizado no processo nacional de acumulação de capital fora excessivamente dependente de determinações alheias ao seu controle. Procuramos argumentar que a dependência venezuelana do petróleo, com todas suas consequências nefastas, se manifesta na reprodução de seu subdesenvolvimento e na subordinação do país aos eventos da política global do petróleo. Graças a isso, a Venezuela, tem o êxito e o fracasso de suas experiências democráticas e econômicas submetidos a desígnios que não controla e que, não raro, estão sob controle de adversários políticos, nomeadamente os Estados Unidos da América.

\section{Referências}

ADGHIRNI, Samy. Petróleo em baixa obriga Venezuela a vender ouro para pagar dívida. Folha de S. Paulo. Mercado. 29 de novembro de 2016. Disponível em <http://www1.folha.uol.com.br/mercado/2016/01/1734769-petroleo-em-baixa-obrigavenezuela-a-vender-ouro-para-pagar-divida.shtml >. Acessado em 01/02/2016 às 18h33min.

AL-RASHEED, Madawi. A History of Saudi Arabia. Nova Iorque: Cambridge University Press, 2010.

Adam Smith em Pequim: Origens e fundamentos do século XXI. Trad. Beatriz Medina. São Paulo: Boitempo, 2008.

O Longo Século XX: Dinheiro, poder e as origens de nosso tempo. Tradução de Vera Ribeiro. Rio de Janeiro: Contraponto, 2012.

ASKARI, Hossein. Collaborative Colonialism: The Political Economy of Oil in the Persian Gulf. Nova Iorque: Palgrave McMillan, 2013. 
ASTORGA, Pablo. La Economía Venezoelana em el Siglo XX. Revista de Historia Económica. N. 3. V. 21. 2003. Pp.623-52.

AZEREDO, Mauro M. A Crise da Democracia Venezuelana: Relações com os Estados Unidos. In: GUIMARÃES, Samuel P.; CARDIM, Carlos H (Orgs.). Venezuela: Visões Brasileiras. Brasília: IPRI, 2003. Pp. 111-156.

BLANCHARD, Christopher M. Saudi Arabia: Background and U.S. Relations. Congressional Research Service Report for Congress. 22 de maio de 2008. Disponível em $<$ https://digital.library.unt.edu/ark:/67531/metadc462604/m1/1/high_res_d/RL33533_2008Ma y22.pdf >. Acessado em 5 de abril de 2017, às $17 \mathrm{hs} 21 \mathrm{~min}$.

BRENNER, Robert. The Economics of Global Turbulence: The Advanced Capitalist Economies from long Boom to long Downturn, 1945-2005. London/New York: Verso, 2006.

CANO, Wilson. Venezuela: Limites para uma nova política econômica. Economia e Sociedade. Campinas. V. 11. N. 1 (18). Jan./jun. 2002. Pp. 95-127.

CAROLLO, Salvatore. Understanding Oil Prices: A Guide to What Drives the Price of Oil in Today's Markets. Londres: John Wiley and Sons Ltd, 2012.

CARVALHO, Carlos Eduardo. Venezuela: petróleo abundante, desenvolvimento difícil. In: PADRÕES de Desenvolvimento Econômico (1950-2008): América Latina, Ásia e Rússia. Brasília: Centro de Gestão e Estudos Estratégicos, 2013. Pp. 351-406.

CHASE-DUNN, Christopher. Global Formation: Structures of the World-Economy, Updated Edition. Maryland: Rowman and Littlefield Publishers, 1998.

EICHENGREEN, Barry. Exorbitant Privilege: The Rise and Fall of the Dollar. Oxford: Oxford University Press, 2011.

ENGDAHL, William. A Century of War: Anglo-American Oil Politics and the New World Order. Londres: Pluto Press, 1992.

FURTADO, Celso. Desenvolvimento e Subdesenvolvimento. Rio de Janeiro: Contraponto/Centro Internacional Celso Furtado, 2009.

Teoria e Política do Desenvolvimento Econômico. São Paulo: Abril Cultural, 1983.

FUSER, Igor. O Petróleo e o Envolvimento Militar dos Estados Unidos no Golfo Pérsico. Dissertação (Mestrado)-Universidade Estadual de São Paulo/Pontifícia Universidade Católica de São Paulo/Universidade Estadual de Campinas. São Paulo, 2005.

GRAMSCI, Antonio. Cadernos do Cárcere: Maquiavel, Notas sobre o Estado e a Política. Tradução de Carlos Nelson Coutinho. Co-edição de Luiz Sérgio Henriques e Marco Aurélio Nogueira. Vol. 3. Rio de Janeiro: Civilização Brasileira, 2000.

GUMIERO, Rafael. Diálogo de Teses do Subdesenvolvimento de Rostow, Nurkse e Myrdal com a Teoria do Desenvolvimento de Celso Furtado. Dissertação (mestrado)Universidade Federal de São Carlos. São Carlos, 2011. 
HIRSCHMAN, A. O. The strategy of economic development. New Haven: Yale University Press, 1958

JEANNOT, Fernando. La Economía Rentista en Venezuela. Análisis Económico. N. 60. V. 25. 2010. Pp. 273-302.

KARL, Terry Lynn. The Paradox of Plenty: Oil Booms and Petro-States. Berkeley/Los Angeles/Londres: University of California Press, 1997.

LUCAS, Gerardo. Industrialización Contemporánea en Venezuela: Política industrial del Estado venezolano 1936-2000. Tese (Doutorado)-Universidad Catolica Andrés Bello. Caracas, 2006.

LUCENA, Romina B. O Desenvolvimento Econômico da Venezuela, 1950/2006. Tese (Doutorado)-Universidade Federal do Rio Grande do Sul. Porto Alegre, 2008.

MCNALLY, Robert. Crude Volatility: The History and Future of Boom-Bust Oil Prices. Nova Iorque: Columbia University Press, 2017.

MELCHER, Dorothea. La Industrialización de Venezuela. Revista Economía. N. 10. 1995. Pp. 57-90.

MORAES, Reginaldo C. C. Estado, Desenvolvimento e Globalização. São Paulo: Editora da UNESP, 2006.

MYRDAL, Gunnar. Economic Theory and Underdeveloped Regions. Harper and Row, 1957.

PANITCH, Leo; GINDIN, Sam. The Making of Global Capitalism: The Political Economy of American Empire. Londres/Nova Iorque: Verso, 2012.

PARRA, Francisco. Oil Politics: A modern history of petroleum. Londres/Nova Iorque: I. B. Taurus. 2004.

PERROUX, François. L’économie du XXème Siècle. Paris: PUF, 1969.

PREBISCH, Raúl. El Desarrollo Económico de la América Latina e Algunos de sus Problemas. CEPAL, 1949.

ROSTOW, Walt. Etapas do desenvolvimento econômico: Um manifesto não comunista. Rio de Janeiro: Zahar Editôres, 1961

SCHULDT, Jurgen; ACOSTA, Alberto. Petróleo, rentismo y subddesarollo: ¿una maldición sin solución? Nueva Sociedad. N. 204. 2006. Pp. 71-89.

SERRANO, Franklin. Relações de Poder e a Política Macroeconômica de Americana: de Bretton Woods ao Padrão Dólar Flexível. In: FIORI, José Luís. O Poder Americano. Petrópolis: Vozes, 2004. Pp. 179-224. 
SHAFFER, Brenda. Energy Politics. Filadélfia: University of Pennsylvania Press, 2009.

TARVER, H. Michael; FREDERICK, Julia C. The History of Venezuela. Londres: Greenwood Press, 2005.

TODARO, Michael; SMITH, Stephen. Economic Development. Nova Iorque: AddisonWesley, 2003.

TORRES FILHO, Ernani Teixeira. O Papel do Petróleo na Geopolítica Americana, In: FIORI, José L. O Poder Americano. Petrópolis: Vozes, 2004. Pp. 309-46.

VAN DER LINDE, Coby. Dynamic International Oil Markets: Oil Market Developments and Structure 1860-1990. Kluwer Academic Publishers, 1991.

WALLERSTEIN, Immanuel. Capitalismo Histórico e Civilização Capitalista. Tradução de Renato Aguiar. Rio de Janeiro: Contraponto, 2001.

Impensar a Ciência Social: Os limites dos paradigmas do século XIX. Tradução de Adail Sobral e Maria Stela Gonçalves. Aparecida: Ideias e Letras, 2006.

. The Inter-state Structure of the Modern World-System. In: SMITH, Steve et. al (Orgs.). International Theory: Positivism and Beyond. Cambridge: Cambridge University Press, 1996. Pp. 87-107.

WALLERSTEIN, Immanuel; HOPKINS, Terence. "Commodity Chains in the WorldEconomy Prior to 1800." Review V. 10, N. 1, 1986. Pp. 157-70.

WILPERT, Gregory. A Venezuela se Afoga em seu Petróleo. Le Monde Diplomatique. 01 de novembro de 2013. Disponível em http://www.diplomatique.org.br/artigo.php?id=1523>. Acessado em 24 de outubro de 2016, às $19 \mathrm{~h} 00 \mathrm{~min}$.

ZAVALA, Maza. La Economia Venezolana em la Decada de los Ochenta. XI Asamblea Nacional de la Federación Nacional de Colegios de Economistas. Puerto la Cruz. Outubro, 1987. Pp. 31-72.

Recebido em agosto de 2018

Aprovado em dezembro de 2018 